\title{
How Palliative and Hospice Care are Organized in Ukraine (Review)
}

\section{A. Wolf (Alexander Wolf)}

All-Ukrainian Association of palliative and hospice

\section{E-mail address:}

info@palliativ.kiev.ua

\section{Reprint address:}

Alexander Wolf

All-Ukrainian Association of palliative and hospice

ul. Tschusewa, 24, of. 11

04060, Kyiv-60

UA

Suource: Clinical Social Work and Health Intervention Volume: 8

Issue: 4

Pages: $99-106$

Cited references: 15

\section{Reviewers:}

Steve Szydlowski

University of Scranton School of Education, USA

Victor Namulanda Wanjala

Catholic University of Eastern Africa, Nairobi, KE

\section{Key words:}

Hospice and Palliative Care. Patients Rights. Reform of Healthcare in Ukraine. Clinical Social Work.

\section{Publisher:}

International Society of Applied Preventive Medicine i-gap

CSWHI 2017; 8(4): 99 - 106; DOI 10.22359/cswhi_8_4_14 @ 2017 Clinical Social Work and Health Intervention

\section{Abstract:}

In the world, Palliative and Hospice Care (PHC) are approaches conceived to improve the quality of life of patients and their families facing the problem associated with life-threatening illness, through the prevention and relief of suffering by means of early identification and impeccable assessment and treatment of pain and other problems; physical; psychosocial; spiritual. In Ukraine, the first efforts to develop PHC already have been made 20 years ago. In 2006-2017 the breakthrough 
was made. In our research, we have analyzed the activities of both governmental bodies and non-governmental organizations in the field of development of PHC. Our main conclusions are that PHC in Ukraine is just starting to develop; the philosophy of PHC just forming. Organizations which develop PHC are very young. As Ukraine is the former Soviet country, paternalistic traditions are very alive here so that many directives, orders and other documents go from above (from Ministry of Health mostly) and the grass-roots are rather rare. As many organizations have not yet undergone training yet, the main directions of the work to develop PHC are advocacy; improvement of the legislation; training for civic leaders, specialists and other stake-holders.

\section{Introduction}

PHC is a modern approach developing globally. The level of its development is defined by many factors - state of humanity, civil society, economics etc. Ukraine is one of the post-Soviet countries which accepts different models and approaches, and PHC is one of them.

\section{Objective}

The aim of our research was to analyze the organizational patterns of the development of PHC in Ukraine: the activities of both governmental bodies and non-governmental organizations in the field of development of PHC.

\section{Methods}

This is a pilot study. Analysis of websites, papers and reviews.

\section{Results}

Results The last research funded by the International Renaissance Foundation in Ukraine declares that in the documents which regulate palliative care for people with HIV / AIDS, there are no detailed mechanisms for collecting data on needs in palliative care. The collection of detailed statistics on palliative care in the sphere of tuberculosis is not foreseen. In the cancer sphere, an electronic register of patients in Ukraine exists which contains detailed data on more than 3 million patients; where the nature of treatment (radical or palliative) is recorded. The experience of implementing and completing the cancer registry can be useful for the development of palliative data collection systems. No other valid statistics on palliative and hospice care exists (Guzij, 2017). According to statistical data of the Association of Palliative and Hospice Care (APHC) and considering WHO recommendations about PHC, at least 500,000 end-oflife patients and nearly 2 million members of their families in Ukraine need supportive care every year (Wolf, 2013). Accordingly to the last official statistics, there are around 42 million people living in Ukraine.

Because this problem was very actual, the first palliative and hospice care initiatives appeared in Ukraine in the first years of independence, after USSR break-down.

In 1990s, the basic governmental organizations in Ukraine which developed palliative and hospice care included those within the structure of Ministry of Health. In 1990s, the basic health care establishments, which provided palliative care in Ukraine, were the hospices; palliative care departments in regional or city hospitals; hospitals of oncological, tuberculosis and 
geriatric profiles; HIV/AIDS centers. Inpatient PHC institutions provided then (and provide now) the medical care and elements of psychosocial and spiritual support. The first formal in-patient hospices in Ukraine were established in Lwiw, Korosten and Ivano-Frankivsk in 1996-1997. Notable, that Lwiw and Ivano-Frankiwsk Hospices have been organized by the local health care administrations as the "special" facilities which have been (and remain now) in the structure of these administrations with the relevant reporting, financing, educational, logistics and other procedures. As one of the founders, The Korosten Hospice had been organized in the form of a charity, with health administration.

Civic society initiatives have been rather week then and did not play an evident role in the development of PHC.

The National State Program Oncology 2002-2006 (which had aimed at the prevention of cancer and improvement of life quality of those with cancer) have mentioned palliative and hospice care, and noted the need of establishing the hospices, but it did not provide the budget for this activity. Anyway, some regions have created hospice (palliative care wards), for example in Kyiv and Lutsk.

In this time some hospices for patients with tuberculosis have been established within the base of some TB hospitals.

In that period (2000s) the activity of NGOs in Ukraine became more evident and encouraged some changes. Advocacy, mobilization and capacity building helped PHC start to be on the agenda for governmental organizations.

Notably, the All-Ukrainian Association of Palliative Care during its monitoring of existing PHC services received formal answers from local health care administrations like:

"Our region has no hospice because the dying patients die at their homes accordingly to the Order of the local health care authority".

PHC services for dying patients at home have not been provided.

Patients' general rights and especially their right to get comprehensive care in the end-of-life have been used as the main message helping to advocate PHC among Ministry of Health Policy-makers. On $11^{\text {th }}$ September, 2008, at the Ministry of Health with the participation of the Minister and representatives of various Churches, a round table was held on the topic Rights of patients in Ukraine. Palliative care: spiritual aspects. Pastoral care for severely ill and $d y$ ing persons. It was a step towards dialogue to coordinate joint actions of physicians and Churches for the sake of health and good for people. For the first time in the history of Ukraine, the Central Executive Authority met with representatives of different denominations not for the sake of politics, but to do something specific for people. As a result of another joint meeting, which discussed the issue of reducing the practice of abortion, a working group on the study of this issue was initiated at the Ministry of Health. In September 2008, a working group elaborated on the Concept of Counter-action to Abortion in Ukraine and conducted the Symposium Moral and ethical aspects of artificial abortion (Bratsun, 2011). Messages considering human rights and humanization /modernization of medical/health care in Ukraine have been used by non-governmental organizations to advocate and encourage PHC development.

\section{Discussion}

As a result, changes to basic Ukrainian Law on organization of health care have been made and PHC was mentioned as a separate level of medical care. The Law became activated on the 1 st of January 2012. Thus the PHC have been legalized as 
in fact no Ukrainian Laws had mentioned or regulated it up to now.

On December 1, 2009, the Department of Palliative and Hospice Medicine of the National Medical Academy of Postgraduate Education was established. A member of the National Academy of Medical Sciences of Ukraine, Doctor of Medical Sciences, Professor Yuri Ivanovich Gubsky was appointed as Head of the Department and continues to be its head in 2017.

From 2015 to 2017 , the transformation of hospitals and HIV/AIDS centers into facilities which provide palliative care continued. For example, the regional HIV/AIDS center in Mykolaiv was transformed into the regional center of palliative support and integrated services. Accordingly, to information of the Regional Health Care Administration, the center provides only the medical component of palliative care.

As we easily can see, the establishing of hospices went from above, mostly from Ministry of Health, and depended on the wish and possibilities of authorities.

As a result, it should be noted that most people still do not have access to comprehensive PHC. In accordance with the data of All-Ukrainian Association of Palliative and Hospice Care as of January 1, 2013 there are 5 inpatient hospices and 13 palliative care departments, which have 521 inpatient beds, and $7 \mathrm{HIV} / \mathrm{AIDS}$ centers (up to 50 beds) in Ukraine established by governmental organizations. Also 3 PHC institutions (about 65 inpatient beds) are charitable and are established by NGOs, and the Local Health Authorities as Co-founders. Also, bed capacity covers only about $20 \%$ of demands for inpatient hospice care (at a rate of 10 beds for palliative patients per 100 thousand population, that is 4,600 beds for Ukraine). Thus, $\mathrm{PHC}$ is provided mainly at home by relatives or carers of patients. These data have shown a significant deficiency of specialized medical institutions in providing PHC to patients and psychological support for their families after the loss of relatives $(9,10)$.

In 2013, International donors and local authorities supported by local non-governmental organizations have initiated a local fundraiser to support creation of the first Children's Hospice in Ukraine. The institution should be created in Nadwirna in Western Ukraine within the structure of the Ministry of Health Institution (so called "Child's hHome"). In 2015, the First Children's Hospice received this criticism from the President's High Commissioner on Children Rights:

"The Nadwirna Child's Home almost does not provide a social component of care; has no social worker, psychologist, lawyer in the staff; any mechanism for interdisciplinary cooperation is absent. Together with small financing, this means that no services could be provided for the ill person and his/ her family" (8).

In 2017, the Institution reduced its Palliative Unit to 10-15 respite beds where severely ill children for several days during their parents short "vacations".

With the support of the United Nations Children's Fund (UNICEF) and in partnership with the Ukrainian-German Medical Association, the law firm ILF and the Kharkiv National Medical University, the Perspective Agency have begun transforming Child's Homes into Rehabilitation, Palliative Care and Early Intervention Centers to provide social-medical services not only for children, but also for families. The purpose of the project, implemented from November 2016 - May 2017, was to create and develop a mechanism for the transformation of residential institutions into centers providing family-oriented services for children with special needs. 
As mentioned above on $1^{\text {st }}$ January 2012, the Law where PHC have been included have been activated. Then in 2013 the former Health Minister Vasyl Knyazevich and his group (League for the support of palliative and hospice care in Ukraine) developed and encouraged implementation of Minister Order \# 41. Upon analysis, we have concluded that the document has rather negative effect on the PHC. The document supports the Ministry of Health as a leading body in the PHC field: underlining that only those organizations which shall have pain management and relevant licenses on medical clinical practice shall be the PHC facilities. The Order encourages the paternalistic approach; non-governmental organizations which face corruption barriers in obtaining state licenses, loose the possibilities to provide $\mathrm{PHC}$.

Notably that the National strategy of health care reform in 2015-2020 (4), elaborated in 2012-2014, mention palliative care just one time and did not regulate it. Anyway, the Law on state financial guarantees of medical services voted by Parliament in the frameworks of the medical reform of 2017 does not mention palliative medical care. It is declared as a free of charge service. The service shall consist of pain evaluation; prescription of drugs; pain syndrome treatment (3).

In the process of analysis of the activities of governmental organizations in PHC development, we have noted that Ministry of Social Policy noted the problem for PHC as well.

In 2008, the Ministry of Social Policy supported an innovative project initiated by the Association of Palliative and Hospice Care for development of PHC in the structure controlled by this Ministry. Also elaboration of methodical recommendations on its development have been done (Wolf, 2011). An innovative project on provision of palliative care for the elderly at home, informs the Ministry of Social Policy, has been successfully implemented for two years. As a result of approbation, since March 1, 2012, a Palliative Care Unit has been established at home. There are more than 100 people in the service at this Department. The Department has Social Workers, a Psychologist, a Physician, a Nurse. All clients are provided with auxiliary medical equipment upon request. Palliative care is carried out in close cooperation with health care facilities. The list of social services includes Palliative/Hospice Care, providing self-service (personal hygiene, medication, feeding); monitoring of health status; assistance in the provision of medical services; assistance in providing technical rehabilitation equipment, training in their use skills; training of the family caregivers; psychological support of a person and family members; assistance in obtaining free legal aid; organization and support of self-help groups (6).

Notably that the Ministry issued another Order which approves the standards for Social Service Home Palliative Care and this document has no allusions to Ministry of Health Orders on PHC. This official document allows various organizations (for example, businesses) to develop this type of care. The State Standard of Palliative Care (the Order of the Ministry of Social Policy of January 29, 2016, № 58) defines the content, norms, conditions and procedure for the provision of Social Care Services in the frameworks of the palliative care. Some institutions in the structure of the Ministry - in Uman, Kyiv, Krasny Kut and other towns and cities have established palliative care units and other similar institutions but multidisciplinary team work and pain management remain rarities here as well. For example, in Uman, within the framework of the social care center offer just 10 palliative care beds (7). Non-governmental organizations (NGOs) activities have been analyzed as well. 
The All-Ukrainian Council for Patients' Rights and Safety in cooperation with the AllUkrainian Association of palliative and hospice care initiated the development of PHC in 2006. Mostly, it was within the framework of international grants of donors affiliated to Soros's Open Society Institute. It was NGOs which have encouraged the development of new documentation, orders, and standards on PHC. In 2006-2009 the All-Ukrainian Association has united and started the advocacy. 2008 was the year of a breakthrough in the field of palliative care. With the support of the Program, the All-Ukrainian Palliative Care Association and the All-Ukrainian Council for the Patient's Rights and Safety, prompted the creation of the Coordination Council for the Development of Palliative Care in Ukraine, the composition and powers of which were approved by a relevant Order of the Ministry of Health. According to the Order of the Ministry of Health, the Council developed and submitted for Ministerial approval the National Program for the Development of Palliative and Hospice Care for 2010-2014. The creation of the National Program allowed not only the introduction of palliative care in Ukraine as part of the General Health Care System, but would also oblige the government to allocate a budget for financing palliative needs and services for the population. The financial and expert support of the Program and the International Palliative Care Initiative also resulted in a 3-week training for health professionals (Doctors, Nurses) providing palliative care. Given the critical shortage of health professionals in this area, the training has significantly contributed to the training of 30 specialists who will further train their colleagues in the regions. The training provided a powerful impact to the implementation of palliative care in Ukraine and the development of a network of facilities providing palliative care services $(5,2)$.
In 2011, the new National League for Support of PHC Development in Ukraine was created. This NGO was founded by the former Minister of Health V.Knyazevich who is its Head of the Board since then. After analysis of news and other posts of the League, we can conclude that the League is rather medically oriented, and regards other elements (psychosocial, spiritual) as additional ones. For example, the Heads of the League in their article state:

"The medical and social analysis of the development of the Provision of PHC to the population of Ukraine has shown that the unsatisfactory state of the PHC system development is largely caused by the insufficient population provision by the specialized PHC facilities homecare teams; lack of staff in PHC facilities; lack of proper motivation for health workers; the need to improve the regulatory framework regulating the provision of PHC to the population; unsatisfactory interdisciplinary collaboration of healthcare workers, both in inpatient and outpatient settings and at home. So that the key problem of PHC in Ukraine is that there are no palliative units" (Gojda et al., 2015).

The Association of Palliative and Hospice Care believes that the key problem for PHC in Ukraine is a weak civic society which should develop the PHC from the grassroots. And, during the development of PHC in Ukraine, the moving force should be not representatives of the health care which need the reform themselves, but civic activists.

Since 2013, after the release of Pain Management Procedures, NGOs provide advocacy and capacity building of Healthcare Workers. Also, NGOs have initiated some positive changes in the formal education on the issue of care for the incurably ill. The Association of Palliative and Hospice Care, for example, cooperates with different medical facilities; organizes study visits; 
clinical placements; other events. This organization pays the greater funding for the development and supporting of grass-roots initiatives and capacity building. Such were the local initiatives on elaboration and implementation of local programs on development of PHC in Cherkassy, Kharkiw, Irpin, Vasylkiw and other cities; conducting the numerous trainings on project management and human rights etc. In its trainings, the Association of $\mathrm{PHC}$ pays great attention to the explanation of the sense of PHC.

The great efforts in advocacy of PHC development belongs to the International Renaissance Foundation which has supported the PHC since 2000s.

In 2016, the Association of Palliative and Hospice Care started a program of education of civic leaders from different regions of Ukraine. Up to 15 trainings and workshops were done in 2016 and 2017.

Notwithstanding the efforts, until now, regional hospices have not been established in Vinnytsia, Dnipropetrovsk, Transcarpathian, Kyiv, Odessa, Poltava, Sumy, Ternopil, Khmelnytsky, Cherkassy, Chernihiv Regions and the City Hospice in Kyiv. In Ukraine there is almost no PHC at home. Only in a few regions, in particular, in the cities of Ivano-Frankivsk, Lutsk, Kharkiv, Kiev, Lwiw, Vynohradiv (Transcarpathian region), at hospices and $\mathrm{PHC}$ departments, there were established mobile home care teams of palliative care, both in public health care institutions, as well as charitable and public organizations.

\section{Conclusion}

The pilot study shows that PHC in Ukraine is just starting to develop. The philosophy of PHC is forming and sometimes it is misunderstood, especially in governmental structures, and non-governmental organizations work to influence better standards of PHC. Organizations which develop PHC are very young. As Ukraine is the former Soviet country, the paternalistic traditions are very alive here so that many directives, orders and other documents go from above and the grass roots are rather rare. As many organizations does not underwent the training yet, the main directions of the work to develop PHC are advocacy, improvement of the legislation, and trainings for civic leaders, specialists, and other stake-holders. Institutes (and PHC is an social institute) are the people and their culture. Sometimes these people are outdated. And we can create the most modern institutes with the best ideas, but if they shall consist of the same outdated people with the same outdated ideas, we shall get the same outdated result. So, to develop PHC in Ukraine, we should develop the culture and civic society, especially, grass-roots initiatives. We believe that NGOs will be the driving force of changes in how we care for incurably ill people in Ukraine. Otherwise, PHC shall become the cargo-cult.

\section{References}

1. BRATSUN OP (2011) Christian view on the activities in the field of palliative care. The need in the institute of Chaplaincy Nursing, № 1, p.5.

2. GOJDA NG, GUBSKI YI, TSARENKO AW (2015) Social and medical aspects of PHC development in Ukraine in the conditions of health care system reform. International Journal Rehabilitation and palliative medicine № 2, p.23-30.

3. GUZIJ OW (2017) Patient-oriented statistics and palliative care in Ukraine Ukrainian Medical Journal, 4 (120) VII/ VIII, p.29

4. WOLF OO (2011) Cooperation between governmental and non-governmental organizations for the development of palliative and hospice care in Pechersk Region of Kyiv Journal of the National Technical 
University. Kyiv Polytechnic Institute, Politology. Sociology. Law. Kyiv, № 1(9), p.109-117.

\section{Internet sources}

1. Department of palliative and hospice medicine [cit.2017-12-10]. Available online: $<$ https://nmapo.edu.ua/index.php/uk/institut-simejnoji-meditsini/kafedra-paliativnoji-ta-khospisnoji-meditsini/346-kafedra-paliativnoji-ta-khospisnoji-meditsini-3>.

2. Development of palliative care in Ukraine. Report on 2006-2008 [cit.2017-12-09]. Available online: <http://www.likar.info/ zdorovye-vsey-semyi/article-43516-rozvitok-paliativnoyi-dopomogi-v-ukrayini-2116-2118rr-zvedenij-zvit/>.

3. Ministry of health discusses the guaranteed complex of free of charge medical services [cit.2017-12-09]. Available online: <http:// moz.gov.ua/ua/portal/pre_20170208_c. html>.

4. National strategy of reforming of the health care system in Ukraine in 2015-2020 [cit.2017-29-09]. Available online: <http:// uoz.cn.ua/strategiya.pdf $>$.

5. Program "Public health" Report by International Renaissance Foundation [cit.201617-09]. Available online: <http://www. irf.ua/files/ukr/programs_health_strategy_1740_ua_PR.pdf $>$
6. Provision of palliative care in Ukraine is an innovation [cit.2017-05-11]. Available online: <http://www.msp.gov.ua/news/11279. html $>$.

7. Structure of the Department of labor and the social care of Uman city council [cit.201711-10]. Available online: <http://umanupszn.gov.ua/strukturi/>.

8. The system of providing of PHC for citizens of Ukraine need the urgent elaboration of the unified standards. [cit.2016-10-03]. Available online: <http://www.ombudsman.gov. ua/ua/all-news/all-activity/30315-pn-sistema-nadannya-paliativnoii-ta-xospisnoii-dopomogi-gromadyanam-ukra/>.

9. TSARENKO A V Development of the Chapter ,Palliative Care " of the State Program ,Health 2020: Ukrainian dimension“ [cit.2017-08-08]. Available online: <http:// ligalife.com.ua/k/1/6_ Carenko.pdf. Accessed 14-05-2013>.

10. WOLF O O Comprehensive needs of terminally ill at the end of life as an important aspect of humanization in the sphere of social policy. [cit.2017-08-08]. Available online: <http://www.palliativ.kiev.ua/index. php?item $=$ articles\&id $=7>$

11. Mykolaiv regional center of pallaitive support and integrated services [cit.2017-0808]. Available online: <http://oblzdrav. mk.gov.ua/index.php/oblasni-94931/oblasniy-snidcentr> 